\title{
MECHANISM OF THE ALTERED BLOOD PRESSURE RESPONSIVENESS PRODUCED BY CHLOROTHIAZIDE *
}

\author{
By EDWARD D. FREIS, ANNEMARIE WANKO, HAROLD W. SCHNAPER AND \\ EDWARD D. FROHLICH
}

\author{
(From the Veterans Administration Hospital and the Department of Medicine, Georgetozen \\ University School of Medicine, Washington, D. C.)
}

(Submitted for publication October 15, 1959; accepted April 22, 1960)

Hypertensive patients respond to chlorothiazide with a reduction of basal blood pressure while normotensive subjects do not $(1,2)$. This is in contrast to other known antihypertensive agents which lower blood pressure whether it is elevated or normal. The specificity of chlorothiazide raised the possibility that it might be a metabolic antagonist of the unknown pressor mechanisms operative in hypertension. Such a position has been taken by Wilkins, Hollander and Chobanian (2, $3)$. Evidence from this and other laboratories, however, indicates that the initial antihypertensive effect of chlorothiazide is a consequence of plasma and total extracellular fluid contraction resulting from the saluretic action of the $\operatorname{drug}(1,4,5)$. The evidence supporting this view follows. 1) The period of falling blood pressure parallels the salt loss and plasma volume reduction and does not precede or follow it $(5,6)$. 2) Massive administration of salt (average $25 \mathrm{~g}$ per day), sufficient partially to overcome the saluretic effect of the drug, tends to reverse the antihypertensive effect (6). 3) Restoration of plasma volume by intravenous dextran infusions, either salt-containing or salt-free, results in partial reversal of the antihypertensive action $(5,7,8)$. The failure of the normotensive subject's blood pressure to fall after chlorothiazide could be due to a lesser saluresis and consequent reduction in plasma volume or to some other mechanism. The present report is concerned with the further elucidation of this problem.

\section{METHODS AND MATERIALS}

The subjects were normotensive patients in the Mt. Alto Veterans Administration Hospital, Washington, D. C., who were convalescing from a variety of illnesses

* Supported in part by Grant H-720 from the National Heart Institute, Bethesda, Md. and by a grant from Merck, Sharp and Dohme, West Point, Pa. not involving the circulatory system (Table I). All patients were ambulatory and asymptomatic at the time the studies were carried out.

Twenty-four-hour urine samples were collected and analyzed for sodium and potassium in 6 subjects as described in a previous communication (8). Body weight was recorded daily for 3 days before and 3 days after chlorothiazide administration. The dosage of the drug was $0.5 \mathrm{~g}$ orally 3 times daily in all instances. All subjects were placed on a diet containing $500 \mathrm{mg}$ salt per day and in addition were given $3.5 \mathrm{~g}$ of salt in tablet form in order to assure a constant salt intake during the study period.

Reactivity to levarterenol (Levophed) was tested in 14 additional subjects who were given the same diet, salt intake and chlorothiazide dosage as indicated above. In 10 of these 14 subjects the response to trimethaphan (Arfonad) also was estimated. Reactivity to levarterenol and trimethaphan was determined as follows. Both agents were diluted in 5 per cent dextrose in water to make up final concentrations of $4 \mathrm{mg}$ levarterenol in $1,000 \mathrm{ml}$ and $500 \mathrm{mg}$ trimethaphan in $500 \mathrm{ml}$. These were given intravenously by the method previously described (9). Control titrations were carried out on the day prior to chlorothiazide administration and the experimental infusions on the third day following chlorothiazide. Immediately thereafter $500 \mathrm{ml}$ of 6 per cent dextran in 5 per cent glucose in water was administered intravenously over a period of 15 to 20 minutes. The infu-

TABLE I

Cumulative negative balances (urinary losses only) of sodium and potassium and decrease in body weight in normotensive subjects given $1.5 \mathrm{~g}$ chlorothiazide daily

\begin{tabular}{|c|c|c|c|c|}
\hline \multirow[b]{3}{*}{ Patient } & \multirow[b]{3}{*}{ Age } & \multicolumn{3}{|c|}{ After 3 days' chlorothiazide } \\
\hline & & \multicolumn{2}{|c|}{$\begin{array}{c}\text { Cumulative neg. } \\
\text { balance }\end{array}$} & \multirow{2}{*}{$\begin{array}{l}\text { Decr. in } \\
\text { body wt. }\end{array}$} \\
\hline & & $\mathrm{Na}$ & $\mathbf{K}$ & \\
\hline & $y r s$ & \multicolumn{2}{|c|}{$m E q$} & $\mathrm{~kg}$ \\
\hline C.T. & 56 & 208 & 100 & 1.6 \\
\hline R.R. & 28 & 258 & 52 & 1.8 \\
\hline W.S. & 36 & 292 & 70 & 2.3 \\
\hline H.B. & 58 & 185 & 130 & 0.4 \\
\hline C.M. & 28 & 474 & 153 & 1.3 \\
\hline P.K. & 35 & 308 & 144 & 4.8 \\
\hline \multicolumn{2}{|c|}{$\begin{array}{l}\text { Mean } \\
\text { SD }\end{array}$} & $\begin{array}{r}287 \\
\pm 103\end{array}$ & $\begin{array}{r}108 \\
\pm 41\end{array}$ & $\begin{array}{r}2.0 \\
\pm 0.7\end{array}$ \\
\hline
\end{tabular}


TABLE II

Mean* arterial pressure, heart rate and hematocrit before and after chlorothiazide in 14 normotensive subjects

\begin{tabular}{|c|c|c|c|c|c|c|}
\hline \multirow[b]{2}{*}{$\begin{array}{c}\text { Sub- } \\
\text { ject }\end{array}$} & \multicolumn{2}{|c|}{$\begin{array}{l}\text { Mean* arterial } \\
\text { pressure }\end{array}$} & \multicolumn{2}{|c|}{$\begin{array}{l}\text { Heart rate } \\
\text { per min }\end{array}$} & \multicolumn{2}{|c|}{ Hematocrit } \\
\hline & Control & $\begin{array}{l}\text { After } \\
\text { drug }\end{array}$ & Control & $\begin{array}{r}\text { After } \\
\text { drug }\end{array}$ & Control & $\begin{array}{l}\text { After } \\
\text { drug }\end{array}$ \\
\hline & \multicolumn{2}{|c|}{$m m \mathrm{Hg}$} & & & \multicolumn{2}{|c|}{$\%$} \\
\hline E.F. & 93 & 88 & 65 & 72 & 52.0 & 56.0 \\
\hline G.T. & 84 & 91 & 69 & 73 & 40.0 & 42.0 \\
\hline J.D. & 100 & 100 & 69 & 68 & 45.8 & 50.5 \\
\hline R.M. & 89 & 103 & 68 & 66 & 38.5 & 45.0 \\
\hline J.B. & 91 & 91 & 78 & 82 & 41.5 & 47.0 \\
\hline R.W. & 93 & 93 & 80 & 86 & 45.2 & 49.8 \\
\hline F.C. & 109 & 105 & 69 & 83 & 48.0 & 54.0 \\
\hline E.C. & 83 & 82 & 75 & 90 & 37.0 & 41.5 \\
\hline D.P. & 91 & 91 & 72 & 83 & 45.8 & 46.8 \\
\hline L.L. & 97 & 98 & 78 & 86 & 48.5 & 50.8 \\
\hline D.I. & 98 & 90 & 65 & 68 & 47.2 & 51.8 \\
\hline G.B. & 100 & 110 & 72 & 84 & 42.5 & 48.5 \\
\hline B.A. & 102 & 99 & 84 & 95 & 46.0 & 52.0 \\
\hline S.D. & 95 & 95 & 64 & 76 & 43.8 & 38.2 \\
\hline Average & 94.7 & 95.5 & 71.8 & 79.5 & 44.4 & 48.0 \\
\hline
\end{tabular}

* "Mean" arterial pressure : $\frac{\text { systolic }+ \text { diastolic }}{2}$.

sions of levarterenol and trimethaphan were again repeated as soon as the administration of dextran was completed. Thus, levarterenol and trimethaphan were infused at the same rates on three separate occasions: before chlorothiazide, following chlorothiazide, and after chlorothiazide plus dextran. Following each levarterenol infusion the blood pressure was allowed to return to the basal level and remain there for at least 10 minutes before the trimethaphan infusion was begun.

\section{RESULTS}

Sodium and potassium losses; body weight changes. Chlorothiazide produced essentially the same degree of sodium loss in the six nonedematous normotensive subjects studied as in nonedematous hypertensive patients $(1,8)$. The "cumulative negative balances" (8) of sodium following three days of continuous treatment with $1,500 \mathrm{mg}$ of chlorothiazide daily averaged 287 (SD 103) $\mathrm{mEq}$ (Table I). The average loss of potassium was 108 (SD 41) $\mathrm{mEq}$. The mean decrease in body weight was 2.0 (SD 0.7 ) $\mathrm{kg}$.

Basal blood pressure and heart rate. The basal blood pressure in the 14 normotensive subjects was essentially unchanged following chlorothiazide. The "mean" (systolic + diastolic/2) blood pressure averaged 94.7 before and $95.5 \mathrm{~mm} \mathrm{Hg}$ after the drug (Table II). This is in contrast to the reductions of basal blood pressure previously observed in hypertensive patients treated with chlorothiazide $(1,2)$. The average systolic pressure in the present group of normotensive subjects decreased slightly from 118 to $114 \mathrm{~mm} \mathrm{Hg}$ and the diastolic increased from 71 to $77 \mathrm{~mm} \mathrm{Hg}$ possibly reflecting the decrease in plasma volume and compensatory vasoconstriction. The average heart rate increased slightly from 72 to 79.5 beats per minute (Table II).

Effects of chlorothiazide on pressor response to levarterenol infusion before and after dextran. The same rate of infusion of levarterenol was carried out on three occasions: 1 ) during the control period, 2) after chlorothiazide, and 3) after restoration of plasma volume depletion with 6 per cent dextran in 5 per cent glucose and water. Effective infusion rates of levarterenol varied between 0.14 and $0.45 \mu \mathrm{g}$ per $\mathrm{kg}$ per minute in different subjects. In eight patients, the responses to several levels of levarterenol infusion were obtained. However, only the responses to the highest infusion rate employed in each of these cases were used for statistical analysis (Table III).

During the control or prechlorothiazide period the mean elevation of systolic blood pressure following the infusion of levarterenol was 26.6 per cent (Table III). After chlorothiazide the response of the systolic pressure to levarterenol was significantly less than in the control period (mean rise, 17.9 per cent ; $p<0.02$ ). Following dextran the responsiveness to levarterenol again increased, the elevation of systolic blood pressure averaging 28.4 per cent. Thus, dextran administration was followed by a significant change in the response of the systolic pressure to levarterenol in the postchlorothiazide period $(\mathrm{p}<0.02)$.

The elevation of diastolic pressure following levarterenol averaged 34.4 per cent in the control period (Table III). After chlorothiazide the mean rise in diastolic blood pressure during the same rates of levarterenol infusion was reduced significantly (mean rise, 18.9 per cent; $\mathrm{p}<0.01$ ). The administration of dextran partially restored diastolic responsiveness, the mean elevation of diastolic pressure being 28.3 per cent. As compared with the levarterenol response immediately preceding dextran, the change was significant at the 0.05 level.

Effects of chlorothiazide before and after dextran on depressor responses to trimethaphan. Ef- 
TABLE III

Per cent changes in systolic and diastolic blood pressure to infusions of levarterenol and trimethaphan before and after chlorothiazide and after chlorothiazide plus dextran*

\begin{tabular}{|c|c|c|c|c|c|}
\hline & $\begin{array}{c}\text { (A) } \\
\text { Before } \\
\text { chlorothiazide }\end{array}$ & $\begin{array}{c}\text { (B) } \\
\text { After } \\
\text { chlorothiazide }\end{array}$ & $\begin{array}{c}\text { p value, } \dagger(\mathrm{B}) \\
\text { compared to }(\mathrm{A})\end{array}$ & $\begin{array}{l}\text { (C) } \\
\text { After chlorothiazide } \\
\text { plus dextran }\end{array}$ & $\begin{array}{c}\mathrm{p} \text { value, }(\mathrm{C}) \\
\text { compared to }(\mathrm{B})\end{array}$ \\
\hline \multicolumn{6}{|l|}{ Response to levarterenol } \\
\hline No. of subjects & 14 & 14 & & 14 & \\
\hline $\begin{array}{l}\text { Systolic blood pressure } \\
\text { Mean change (\%) } \\
\text { SD }\end{array}$ & $\begin{array}{r}+26.6 \\
8.8\end{array}$ & $\begin{array}{r}+17.9 \\
8.3\end{array}$ & $<0.02$ & $\begin{array}{r}+28.4 \\
11.6\end{array}$ & $<0.02$ \\
\hline $\begin{array}{l}\text { Diastolic blood pressure } \\
\text { Mean change }(\%) \\
\text { SD }\end{array}$ & $\begin{array}{r}+34.4 \\
13.4\end{array}$ & $\begin{array}{r}+18.9 \\
12.0\end{array}$ & $<0.01$ & $\begin{array}{r}+28.3 \\
9.1\end{array}$ & $<0.05$ \\
\hline \multicolumn{6}{|l|}{ Response to trimethaphan } \\
\hline No. of subjects & 10 & 10 & & 10 & \\
\hline $\begin{array}{l}\text { Systolic blood pressure } \\
\text { Mean change (\%) } \\
\text { SD }\end{array}$ & $\begin{array}{r}-8.5 \\
4.8\end{array}$ & $\begin{array}{r}-14.9 \\
11.2\end{array}$ & $>0.05$ & $\begin{array}{r}-10.9 \\
7.6\end{array}$ & $>0.05$ \\
\hline $\begin{array}{l}\text { Diastolic blood pressure } \\
\text { Mean change }(\%) \\
\text { SD }\end{array}$ & $\begin{array}{r}-7.0 \\
7.7\end{array}$ & $\begin{array}{r}-11.1 \\
14.9\end{array}$ & $>0.05$ & $\begin{array}{r}-7.6 \\
6.4\end{array}$ & $>0.05$ \\
\hline
\end{tabular}

* Tests were paired in that infusion rate of levarterenol or trimethaphan utilized in any one test in A was duplicated in $B$ and $C$.

$\dagger$ Value calculated as follows:

$$
\begin{aligned}
\mathrm{SE}(\mathrm{A}-\mathrm{B}) & =\sqrt{\frac{\mathrm{SD}(\mathrm{A})^{2}}{\mathrm{n}(\mathrm{A})}+\frac{\mathrm{SD}(\mathrm{B})^{2}}{\mathrm{n}(\mathrm{B})}}=\text { standard error of the difference } \\
\mathrm{t} & =\frac{\text { mean }(\mathrm{A})-\text { mean }(\mathrm{B})}{\mathrm{SE}(\mathrm{A}-\mathrm{B})} .
\end{aligned}
$$

fective rates of infusion of trimethaphan varied between 0.03 and $0.11 \mathrm{mg}$ per $\mathrm{kg}$ per minute. The modifying effects of chlorothiazide and chlorothiazide plus salt-free dextran on the blood pressure responsiveness to trimethaphan were studied in 10 subjects (Table III). The mean reduction of systolic blood pressure was 8.5 per cent in the control period and 14.9 per cent after chlorothiazide to the same levels of trimethaphan infusion. Following dextran the fall in systolic pressure during trimethaphan averaged 10.9 per cent. The mean decrease in diastolic pressure during trimethaphan infusion was 7.0 per cent in the control period, 11.1 per cent after chlorothiazide and 7.6 per cent following dextran. Although these alterations suggested that chlorothiazide enhanced the diastolic pressure fall produced by trimethaphan, and that dextran partially reversed both the systolic and diastolic responses, the changes were not statistically significant.

Twelve of the 14 subjects exhibited a decrease in body weight greater than $0.5 \mathrm{~kg}$ following chlorothiazide. The mean decrease in weight for the entire group was $-1.4 \mathrm{~kg}$. The hematocrits of the 14 subjects averaged 44.4 per cent before chlorothiazide and 48.0 per cent following the drug (Table II). No cause was found for the decrease, rather than the expected increase, in hematocrit of Subject S.D.

\section{DISCUSSION}

In nonedematous hypertensive patients the negative balance of sodium as estimated by urinary excretion during the first four days of treatment with chlorothiazide averaged $250 \mathrm{mEq}(1,8)$, which is similar to the loss of sodium observed in the present study in nonedematous normotensive subjects. The loss of body weight also was similar since the average weight loss was $2.0 \mathrm{~kg}$ in the hypertensive patients (8). Although plasma volume was not estimated directly in the present investigation in normotensive subjects, the significant elevations of hematocrit indicated the presence of hemoconcentration due to plasma volume reduction. It is probable, therefore, that the body fluid 
changes were similar in both hypertensive and normotensive, nonedematous subjects.

Despite the fact that the body fluid changes were similar in the previously reported hypertensive patients and in the present series of normotensive subjects, the normotensive group failed to exhibit a reduction of basal blood pressure after chlorothiazide. The hypertensive patient under similar conditions (hospitalization with $4.25 \mathrm{~g}$ salt intake daily) displayed a reduction of "mean" (systolic + diastolic/2) blood pressure averaging 15 per cent less than the pretreatment level (1). It is of interest that this value is quantitatively similar to the 13 per cent reduction in the levarterenol pressor response of normotensive subjects following chlorothiazide.

The reduction of basal blood pressure in the hypertensive patient could be due to a specific antagonistic effect of chlorothiazide on the unknown pressor factors which maintain essential hypertension. But it could also be due to a nonspecific decrease in "reactivity" to any or all types of pressor influences. Evidence for the latter is provided in these studies. Reactivity to a controllable pressor stimulus, namely, levarterenol infusion, was reduced after chlorothiazide. Similar observations have been made by Merrill, Guinand-Baldo and Giordano, in hypertensive patients (10). Beavers and Blackmore found in normal dogs that chlorothiazide reduced reactivity to a variety of pressor agents (11).

Previous reports have shown that repletion of plasma volume with infusions of dextran, either salt-containing or salt-free, combats the depressor effect of chlorothiazide in hypertensive patients $(5,7,8)$. The present studies indicate that restoration of plasma volume depletion with saltfree dextran combats the altered blood pressure responsiveness produced by chlorothiazide in normotensive subjects. It seems possible, therefore, that both the reduction of basal blood pressure in hypertensive patients and the altered reactivity seen in either hypertensive or normotensive subjects is due at least in part to the reduction in plasma volume.

An objection has been raised that the above concept does not explain the long-term antihypertensive effects of chlorothiazide $(3,12)$. After several months of continuous treatment the plasma volume often is retored despite continued reduction of blood pressure (8). However, the mechanism of action of antihypertensive agents is difficult to interpret after long continued treatment because the severity of the hypertension may abate under the effects of prolonged blood pressure control (13), and drug tolerance may enter to further confuse the picture. It seems unlikely that chlorothiazide reduces blood pressure by one mechanism initially and by an entirely different mechanism at a later time.

The failure of chlorothiazide to influence significantly the depressor response to trimethaphan was surprising in view of the clinical observations that chlorothiazide enhances the effectiveness of ganglion-blocking drugs in hypertensive patients $(1,2,4)$. However, it is evident from the results in Table III that the blood pressure of the supine, normotensive subject is not very responsive to ganglion blockade. This provided a relatively insensitive test subject for the study. It is possible that significant changes would have been found if the more responsive hypertensive patients had been used.

\section{SUMMARY}

Chlorothiazide lowers basal blood pressure only in hypertensive and not in normotensive individuals. However, after chlorothiazide in normotensive subjects, reactivity is reduced to levarterenol. The saluretic response, weight loss and decrease in plasma volume following chlorothiazide are similar in hypertensive and normotensive subjects. Plasma volume replacement with salt-free dextran which tends to restore pretreatment basal blood pressure in hypertensive patients also tends to restore pretreatment responsiveness to levarterenol in normotensive subjects.

These observations suggest that basal blood pressure is lowered by chlorothiazide specifically in the hypertensive patient because the reduction in plasma volume produced by the drug diminishes blood pressure responsiveness to the unknown pressor mechanisms operative in that disorder. This concept does not rule out the possibility that additional factors may contribute to the antihypertensive effects of chlorothiazide and other saltdepleting procedures. 


\section{ACKNOWLEDGMENTS}

The authors are indebted to Mary J. Taylor and Doris Roberts for valuable technical assistance.

\section{REFERENCES}

1. Freis, E. D., Wanko, A., Wilson, I. M., and Parrish, A. E. Chlorothiazide in hypertensive and normotensive patients. Ann. N. Y. Acad. Sci. 1958, 71, 450.

2. Wilkins, R. W., Hollander, W., and Chobanian, A. V. Chlorothiazide in hypertension: Studies on its mode of action. Ann. N. Y. Acad. Sci. 1958, 71, 465.

3. Hollander, W., Chobanian, A. V., and Wilkins, R. W. Studies on the antihypertensive action of chlorothiazide. Clin. Res. 1958, 6, 21.

4. Tapia, F. A., Dustan, H. P., Schneckloth, R. A., Corcoran, A. C., and Page, I. H. Enhanced effectiveness of ganglion-blocking agents in hypertensive patients during administration of a saluretic agent (chlorothiazide). Lancet 1957, $2,831$.

5. Dollery, C. T., Harington, M., and Kaufmann, G. The mode of action of chlorothiazide in hypertension. With special reference to potentiation of ganglion-blocking agents. Lancet 1959, 1, 1215.

6. Freis, E. D. Treatment of hypertension with chlorothiazide. J. Amer. med. Ass. 1959, 169, 105.
7. Freis, E. D. The effects of salt and extracellular fluid depletion on vascular responsiveness with particular reference to chlorothiazide in Hypertension, F. R. Skelton, Ed. New York, American Heart Ass., 1959, vol. VII, p. 9.

8. Wilson, I. M., and Freis, E. D. The relationship between plasma and extracellular fluid volume depletion and the antihypertensive effect of chlorothiazide. Circulation 1959, 20, 1028.

9. Freis, E. D., MacKay, J. C., and Oliver, W. F. The effect of "sympatholytic" drugs on the cardiovascular responses to epinephrine and norepinephrine in man. Circulation 1951, 3, 254.

10. Merrill, J. P., Guinand-Baldo, A., and Giordano, C. The effect of chlorothiazide on norepinephrine response in human hypertension. Clin. Res. 1958, 6, 230.

11. Beavers, W. R., and Blackmore, W. P. Effect of chlorothiazide on vascular reactivity. Proc. Soc. exp. Biol. (N. Y.) 1958, 98, 133.

12. Winer, B. M. Studies on the content and distribution of sodium, potassium and water in arterial hypertension (abstract). Circulation 1958, 18, 800.

13. Perry, M. H., Jr., and Schroeder, H. A. Studies on control of hypertension. VI. Some evidence for reversal of process during hexamethonium and hydralazine therapy. Circulation 1956, 13, 528. 